\title{
シンクログラフィーによる中性脂質の 定量に関する研究
}

\author{
田 中正康 - 伊藤俊洋 - 金子弘 \\ 北里大学教養部化学研究室 (相模原市麻满台 1 )
}

\section{Quantitative Determination of Neutral Lipids on Thin Layer-FID Chromatography}

\author{
Masamichi Tanaka, Toshihiro IтOH and Hiroshi Kaneko \\ Division of Chemistry, School of General Studies, Kitasato University \\ (1, Asamizodai, Sagamihara, Kanagawa)
}

\begin{abstract}
Responses of sterol, fatty acid, sterol ester and triglyceride on a quantitative thin layer chromatographic apparatus which was equipped with a flame ionization detector were determined using with six kinds of neutral lipid mixtures. These responses were represented as relative responses against to triglyceride response and converged within maximum error of $5 \sim 10 \%$ (S.D.) over a range of loads (2 10 $\mu \mathrm{g}$ lipid). All of the relative responses were in proportion to the weight ratio. It was found that the method is very superior and convenient means for the quantitative estimation of neutral lipid compositions.
\end{abstract}

\section{1 緒 言}

複雑な脂質混合物中の各成分を定量するためには，カ ラムクロマトグラフィー, 薄層クロマトグラム上に分離 した各スポット部位をデンシトメーターで測定する方 法，また溥層からかき取り比色定量する方法，あるい は最近では高速液体クロマトグラフィーなど種々試みら れている(1),2)。しかしこれらの方法は, 簡便さ, 正確さ， 感度などのうち, いずれかの点で何らかの難点があり， それぞれ一長一短がある。

薄層クロマトグラフィー（TLC）と水素炎イオン化検 出器 (FID) とを組み合わせたシンクログラフィーは,

TLC により分離した有機化合物を水素炎中で燃焼させ,

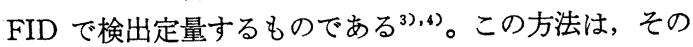
簡便性と高、感応性, および有機化合物であればすべて 検出が可能であることなど，脂質の定量分析への応用に も大いに期待すべきものがあると考えられる。特に, 特 異的な検出反応がなく不飽和度により呈色性の差の大き い中性脂質類の分析に有利と考えられる。しかし，これ までこの方法による脂質の定量分析については, 一, 二 の試みはなされてはいるが5゙,6), 定量的応用について, 詳細な検討は行われていない。また，最近シンクログラ フィーに用いる TLC 用ロッドとして, ケイ酸, アル ミナなどを石英棒に燒結したものが開発された。このも つは, 反復使用が可能であり，また，層がはげ落ちるこ
とがないので，炭酸水素ナトリウム，ホウ酸などの溶液 に浸すことにより，いろいろな試薬で処理したロッドを 作ることも容易であり，従来使われていたケイ酸塗布口 ッドに比べて，その有用性は更に飛躍的に向上するもの と思われる。

今回, 中性脂質の定量分析にシンクログラフィーがど の程度の信頼性をもって応用できるかを詳細に調べた。

\section{2 実験}

\section{$2 \cdot 1$ 装 置}

THINCHROGRAPH (TFG-10型，ヤトロン製）に 2 ペン記録計（日立 056型）を組み合わせたもので，クロ マトグラムおよびそれぞれのピーク面積が同時に記録さ れるものを使用した。

\section{2 ロッド}

外径 $0.9 \mathrm{~mm}$, 長さ $15 \mathrm{~cm}$ の石英棒にケイ酸を融着 させたケイ酸融着ロッド（商品名シンクロッド，ヤトロ ン製)を使用した。

\section{3 試 料}

ステアリン酸およびパルミチン酸（ガスクロマトグラ フィーで純度 $99.9 \%$ 以上を確認) は日本油脂から提供 された。コレステロールは関東化学製 (一級試薬), ま たトリパルミチンは日本グリセライド工業製を用いた。 コレステロールパルミテートは上記コレステロールとパ ルミチン酸から合成したものを使用した。上記のそれぞ 
Table-1 Composition of standard mixtures.

\begin{tabular}{c|c|c|c|c}
\hline \multirow{2}{*}{ Sample } & \multicolumn{4}{|c}{ Composition of wt \% } \\
\cline { 2 - 5 } & Cholesterol & Stearie acid & Tripalmitin & Cholesteryl palmitate \\
\hline A & $23.56(0.79)$ & $22.66(0.76)$ & $29.69(1.00)$ & $24.08(0.81)$ \\
B & $31.27(1.54)$ & $26.19(1.29)$ & $20.33(1.00)$ & $22.18(1.09)$ \\
C & $16.71(0.36)$ & $22.21(0.57)$ & $46.31(1.00)$ & $14.78(0.32)$ \\
D & $20.00(1.35)$ & $37.10(2.51)$ & $14.81(1.00)$ & $28.09(1.90)$ \\
E & $13.06(0.21)$ & $12.15(0.19)$ & $62.85(1.00)$ & $11.94(0.19)$ \\
F & $24.57(0.85)$ & $20.96(0.73)$ & $28.83(1.00)$ & $25.63(0.89)$ \\
\hline
\end{tabular}

( ) : Weight ratio to tripalmitin

れの試料を Table-1 に示した組成に混合したものを栵 準脂質混合物として使用した。

\section{4 試 薬}

実験に用いた溶媒（石油エーテル，ジエチルエーテ ル，䣷酸，クロロホルム，メタノール）は，それぞれ市 販一級試薬を全共通すり合わせガラス器具で蒸留したも のを使用した。

\section{5 分析法}

約 $1 \mu l$ の標準脂筫混合物 $(20 \sim 30 \mu \mathrm{g})$ のクロロホル ム溶液を，マイクロシリンジを用いてケイ酸融着ロッド 上にスポットし, 溶媒系; 石油エーテル：エーテル：酢 酸 $(90: 10: 1, \mathrm{vol} / \mathrm{vol})$ で展開㣪, ロッドは温風で $1 \mathrm{~min}$ 風乾し，さらに五酸化リン上，真空デシケーター中で 10 $\min$ 乾燥したの占，シンクログラフにかけた。シンクロ グラフの条件は, 水素流速 ; $125 \mathrm{ml} / \mathrm{min}$, 空気流速 ; $2000 \mathrm{ml} / \mathrm{min}$ ，スキャンニング速度 ；200 mm/min，チャ 一下速度 ; $240 \mathrm{~mm} / \mathrm{min}$, 検出器の電圧 ; $50 \mathrm{mV}$, 記録 計の電压；100 mV で行った。クロマトグラフィー用 融着ロッドは，FID による検出と同時に再活性化が行 われており，そのまま直ちに再使用することができた。 なお，この装置では，融着ロッドを10本連続的に測定で きるので，原則として一度に10本のロッドを同時に分析 した。ロッドは特に分離の悪いもの（100本中 2 3 本） を除き，ランダムに使用した。クロマトグラムの面積は 積分曲線から読みとり, その際, 積分曲線がフルスケー ルになる場合の面積を 25.0 とした。

\section{3 結果と孝察}

ケイ酸融着ロッドを用いて，標準脂質混合物をシンク ログラフで分析した場合に得られたクロマトグラムの一 例を Fig.-1 に示した。この場合の脂質成分の相互分離 は, 石油エーテル : エーテル : 酢酸 (90: $10: 1, \mathrm{vol} / \mathrm{vol}$ ) の系で充分効果的であることがわかり，主としてこの系 を用いて以下の実験を行った。また，シンクログラフの 操作条件は, 2.5 分析法の中で示した条件が分離, 感度 ともに良いことがわかったので，本実験はこの条件に従 った。なお, 特定のロッドを選び出し, これを繰り返し 使ってゆくことで，より一層再現性の良い結果を得るこ

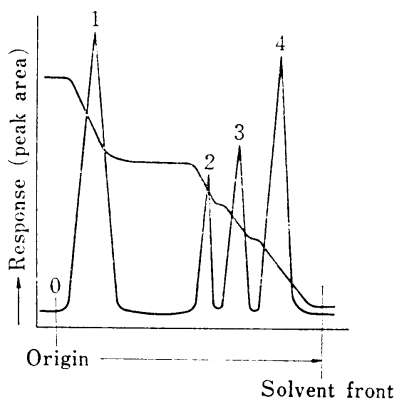

1: Cholesterol 2: Stearic acid 3 : Tripalmitin 4 : Cholesteryl palmitate Sample A was spotted on a silicic acid rot, Mobile phase;petroleum ether-ethyl ether-acetic acid(90: $10: 1)$

Fig.-1 Thinchrogram of the standard mixture A.

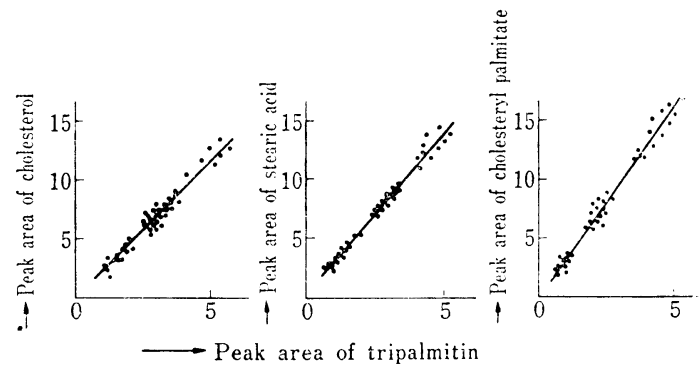

Fig.-2 The influence of sample size on the ratio of peak area of cholesterol, stearic acid, cholesteryl palmitate to that of tripalmitin. Sample D.

とができると考えられるが，莑際の分析では，このよう な分析法をとることはむしろ困難なため，本実験では， 不特定ロッドをランダムに使用して分析安行った。

まず，スポット量を変えた場合，各脂質のトリパルミ チンに対する面積比がどのように変わるかを調べた。試 料として混合物 Dを用い，各脂質成分の量を $2 \sim 10 \mu \mathrm{g}$ の範囲でスポット量を変えて測定した結果を Fig.-2に まとめた。各脂質の面積とトリパルミチンの面積との間: には，以ずれの脂質においてもよい直線関倸があること がわかった。したがって，少なくとも $2 \sim 10 \mu \mathrm{g}$ の範囲 
Table-2 Reproducibility of peak area ratio ${ }^{a}$.

\begin{tabular}{l|r|r|r|r}
\hline \multicolumn{1}{c|}{ Lipids } & Tripalmitin & Cholesterol & Stearic acid & Cholesteryl palmitate \\
\hline Average peak area ratio & 1.00 & 1.13 & 0.69 & 1.17 \\
Standard deviation & & \pm 0.11 & \pm 0.04 & \pm 0.07 \\
Weight ratio & & 0.79 & 0.76 & 0.81 \\
\hline
\end{tabular}

Means of seventy experiments

Sample : sample A

a) Ratio of peak area of each component to that of tripalmitin.

b) Ratio of weight of each component to that of tripalmitin.

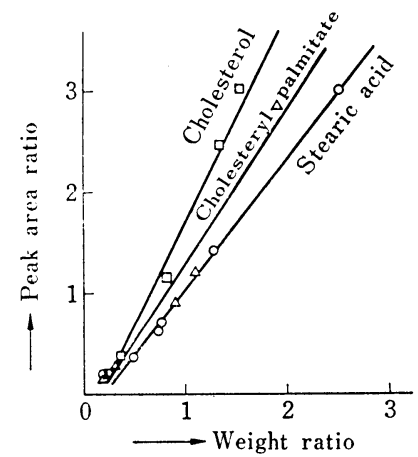

Fig.-3 The relationships between the ratio of peak area and that of weight for cholesterol, stearic acid and cholesteryl palmitate to tripalmitin.

であれば，スポット量を一定にしなくても各脂質のトリ パルミチンに対する面積比は常に一定であることがわか った。

そこで次に，試料 A〜F（Table-1）をシンクログラ フにかけ, 各脂質のトリパルミチンに対する面積比と重 量比との関倸を調べ，得られた結果をまとめて Fig.-3 に示した。Fig.-3 のグラフに見られる通り,トリパル ミチンに対するステアリン酸の面積比と重量比との間に は，ほぼ 1:1 の直線関係があることがわかった。しか し, 遊離コレステロール，コレステロールパルミテート の場合は, 面積比が必ずしも重量比を反映せず, 面積比 が重量比より大きくなる傾向が見られた。したがってス テロール誘導体に対しては, 面積比を Fig.-3 のグラフ を用いて重量比に換算する必要があることがわかった。 実際に天然物の中性脂質組成を分析する場合には, 脂肪 酸は炭素鎖長および不飽和度の異なるものの混合物であ るし，ステロール類もいくつかの同族体の混合物である
ので，シンクログラフィーを用いて各成分の厳密な組成 比を得ることは困難であるが，Fig.-3 のグラフを用い ることにより, 遊離脂肪酸類, ステロールエステル類, 遊離ステロール類の各グループの含有量をそれぞれステ アリン酸, コレステロールパルミテート，コレステロー ルに換算した分析值として算出できることがわかった。 なお，各中性脂質混合物 $(\mathrm{A} \sim \mathrm{F})$ を分析し，20〜70例 のシンクログラムから得られた各中性脂質組成の分析值 は，それぞれ標準偏差 $\pm 5 \sim 10 \%$ の範囲で再現性のある ことがわかった。このうち混合物 Aについての結果を,

Table-2 にまとめて示した。

以上述べた実験から，この方法は，簡便さ, 正確さ, 感 度, 経済性などにすぐれており, 特に中性脂質など特異 的検出反応の少ないもの，あるいはあってもはん蓶なも の, あるいは均一な反応を示さないものなどの定量法と して非常に有用な分析法の一つであることがわかった。

さらに極性脂質の定量分析にシンクログラフィーを用 いる分析法について検討を進めている。

本研究の一部は昭和 49 年度油化学研究発表会 (昭和 49 年 11 月 2 日，大阪）で発表したものである。

（昭和50年10月16日受理）

\section{文献}

1) M. Kates, "Laboratory Techniques in Biochemistry and Molecular Biology, Techniques of Lipidology”, North-Holland, London (1972) p. 393

2) 金子 弘, 油化学, 22, 499 (1973)

3) J.J. Szakasits, P.V. Peurifoy, L.A. Woods, Anal. Chem., 45, 351 (1970)

4) K.D. Mukherjee, H. Spaans, E. Haahti, J. Chro. matogr., 61, 317 (1971)

5）奥村 保, 上遠野哲郎, 分析化学, 22, 980 (1973)

6) 日本生化学会編, “生化学実験講座 3 脂質の化学”, 東京 化学同人, (1974) p. 58 